\title{
Social Capital and Unseen Inequalities: The Case of Tourism Cluster Dialogue Forum (FRK- Forum Rembuk Klaster)
}

\section{Lesta Karolina Br. Sebayang and Sri Utami}

Department of Development Economics, Faculty of Economics, Universitas Negeri Semarang

\section{Abstract}

The aim of this study is to seek how interpersonal relations among the group members are built and to what extent relations between members can bring certain possible inequalities in the long run for local community. It is a qualitative method employing a two-stage research design. The first was distributing questionnaires to gather data on the profile of the members. There were thirty respondents involved for fulfiling the

Corresponding Author: Lesta Karolina Br. Sebayang lesta.fe@mail.unnes.ac.id

Received: 7 August 2018 Accepted: 15 September 2018 Published: 22 October 2018

Publishing services provided by Knowledge

(c) Lesta Karolina Br. Sebayang and Sri Utami. This article is distributed under the terms of the Creative Commons

Attribution License, which permits unrestricted use and redistribution provided that the original author and source are credited.

Selection and Peer-review under the responsibility of the ICE-BEES 2018 Conference Committee. questionnaires. Then, last but not least was in-depth interview aiming to get deeper information on how the members involved in the activity conducted by the local government. The interview was addressed to five active members of the forum. This study found that strong bonding social capital existed within the group and to some extent it could create unseen inequalities to other members of the group because it makes them have less access to experience offered opportunities from facilitating parties. The paper was limited to a rather small dialogue forum and focused on a few active members of the group. This was due to the strong ties happened among these active members. It is expected that local government should provide wider opportunities, especially by facilitating members of the group who have less access to benefit from resources, and ensure to improve their capacity to benefit from the available opportunities not only for certain people. This paper informs everyone interested in developing local community, especially local government or facilitator, that inequalities could happen even though the strong ties among members have existed. This inequality is not necessarily literally known by the disadvantage groups in the short run, but, in the long run, these group could be left behind.

Keywords: social capital, dialogue forum, tourism cluster, local development

\section{Introduction}

In Indonesia, Small and medium entreprises (SMEs) play significant role in contributing G OPEN ACCESS the economic growth. The statistic data in 2006 indicated that there were $83,3 \%$ of 
SMEs out of total enterprises that were able to employ two people each unit. Related to cluster, used to be known as "sentra", Central Java provincial government has made an approach to develop SMEs. These SMEs are agglomerated and interconnected which then lead to a pool of enterprises to make them easier to develop and to improve. This is also related to decentralization era which requires local government to be able to prioritize the role of the society in planning, and implementation process as well as the monitoring and evaluation based on local indigenous resources.

The local economic development (LED) is any initiative executed by interest stakeholders collectively either by private sector, public sector, and society aimed to increase economic growth and create job opportunities. Therefore, LED is expected to accelarate economic growth to achieve better life for people. To gain this, Central Java provincial government takes one of the approaches in LED- that is cluster. Cluster is simply defined as the agglomeration of related industries and their institutions which are geographically connected [9]. Meanwhile, Porter (1998) defines cluster as an agglomeration of geographically interconnected enterprises and supporting institutions.

In 2010, a coordination meeting hosted by Forum for Economic Development and Resources Central Java province reported that in Central Java province, there are 150 SMEs clusters consists of 87 industrial cluster, 49 agricultural cluster, and 14 tourism cluster. Their existence has been acknowledged by national government. The central government has stated that the program of local economic development acceleration in the province grows faster than that of other provinces. However, the dynamics of cluster development should be more aware of in accordance to achieve a better approach on cluster development implementation.

In Addition, to make the approach better applied, provincial government established a forum consisting interest stakeholders which include public and private sectors, parlements, universities, association, and other non-goverment organizations to discuss policies for cluster development. This Forum is called Forum Pengembangan Ekonomi dan Sumber Daya (FPESD- Forum for Economic Development and Resources). This platform is available in the provincial level. Meanwhile, in every regency/city in Central Java, they have Forum for Economic Development and Employment Promotion-FEDEP. And, in the local level, it is called Cluster Dialogue Forum- Forum Rembug Klaster (FRK). These platforms aimed to support the cluster development.

Cluster Dialogue Forum (FRK), a platform established at the business unit, is interesting to be assessed since its existence is dynamic and plays role as a driving force of any form of initiative from the members of the cluster and is assumed to have many 
kinds of informal institutions. Therefore, it is considered to be interesting to review deeper on its benefit, and role in improving the performance of the stakeholders.

\section{Literature Review}

\subsection{Tourism cluster}

A study on tourism cluster (Huybers and Bennet: 2003; Meler et al: 2003), mentions that tourism cluster is considered to be one of significant elements in economic condition in many countries. Tourism sector will greatly give impacts to economy if it is formulated competitively. For instance by creating and promoting attractive tourism destination.

Melet $(2003 ; 25)$ mentions that the role of cluster at the business unit level in tourism sector should be considered significant in benefitting the society. For instance the tourism cluster in Croatia. The study results that the tourism cluster requires particular treatment and effort to enable tourism elements actively produce their best initiatives for their development. In addition, the study conducted by Timur and Getz (2008:445) on cooperation among stakeholders of tourism cluster indicates that the government and organization management of tourism destination have more authority and legitimation to develop the tourism sector compared to other related parties.

The benefit of agglomeration for business unit covers the easiness in accessing the raw material, research and development facilities, skillfull labours, more established supporting institution, and the raw materials market growth [18]. The system of cluster offers benefit such as collective efficiency, and cooperation among cluster $[1,20]$. This cooperation is often done in term of raw material provision, marketing, common product, availability, and services from other third parties. The others are possibility of lower cost for transaction, the opportunities for new enterprises due to more information exchange, product innovation dialogues, etc.

Figure I shows related elements supporting the cluster dialogue forum in Borobudur. The cluster dialogue forum members consist of many elements. They are the business unit, the supporting institution, the cluster manager, and the business development service provider. The business unit can be classified in industry, agriculture, and tourism. Next, the supporting institutions include government, FEDEP, FPESD, private institution, and non-govermental organization. This research focuses on the factors contributing to the interactions among members and their factors on enhancing the performance of the FRKPB as a dialogue platform among cluster members. 


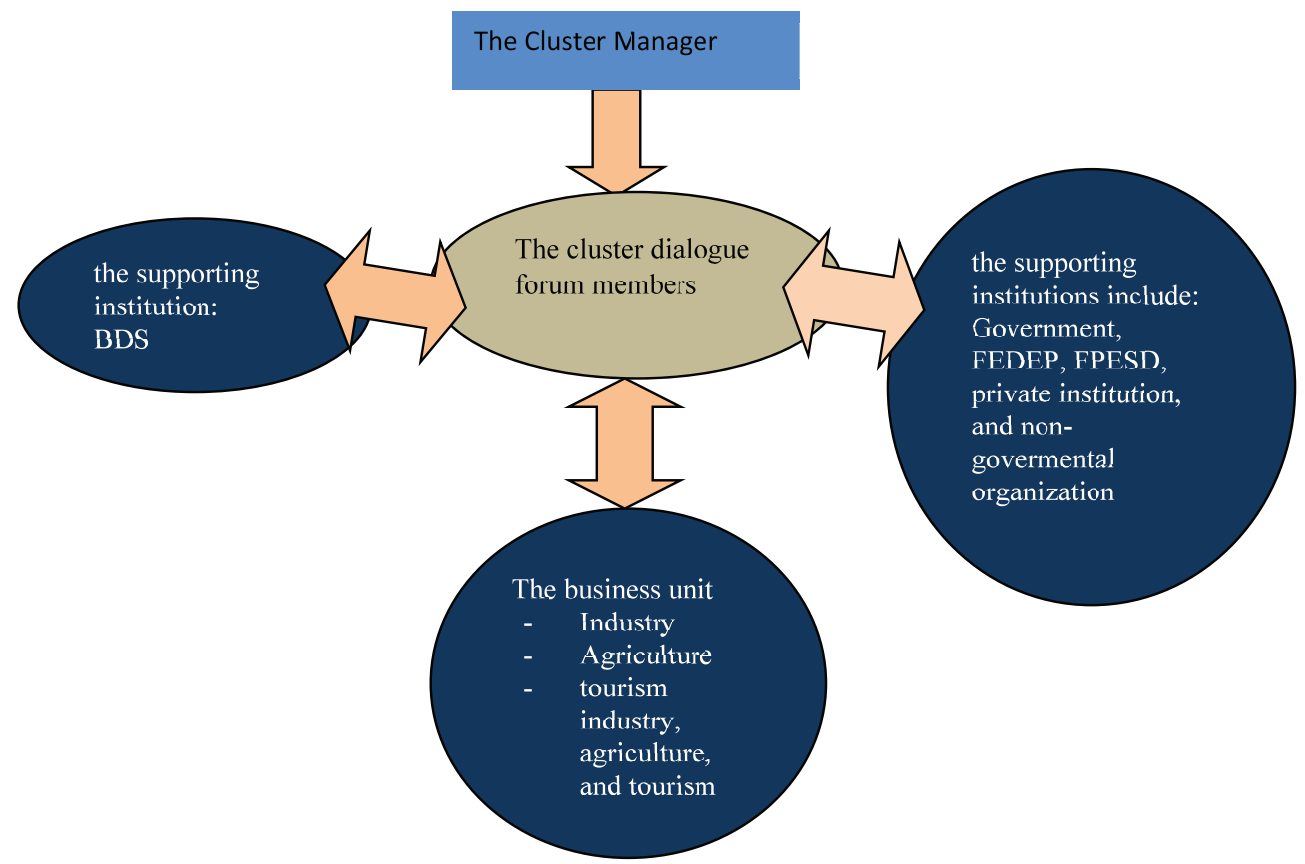

Figure 1: A Pattern of Tourism Cluster Dialogue Forum in Central Java (Source: FPESD, 2006).

\subsection{Social capital}

Cluster is famous as one of instruments to promote local economic development. It benefits actors involved to due its concentration in certain area.

Clusters are geographically proximate group of interconnected companies and associated institutions in a particular field linked by commodities and complementarities. Clusters encompass an array of linked industries and other entities important to competition....including governmental and other institutions-such as universities, standard setting agencies, think tanks, vocational training providers and trade assocations [17].

Clustering in certain area benefits enterprises in term of cost, economies of scale and scope, specialisation, pool of information exchange on market, technology and learning process. These "hard" aspects are some identified by Marshal (1890) in Anderson, Hanson, Serger and Sorvik. There are other equally significant factor derived due to clustering. It is a "soft factor" (in [1]) mentioned by Putnam (1993, 2000). It is related to the norms or values and trust which exist in the social network. It leads to the notion of social capital which open more opportunities for peoplein the social network to have mutual benefit due to the reciprocal activities. 
In addition, World Bank in Knorringa and van Staveren (2005) defines social capital as "the institutions, the relationships, the attitudes and values that govern interactions among people and contribute to economic and social development". Others, Bourdieu (1980) in Milani mentions that social capital is "a set of real potential resources resulting from belonging, for an extended period and institutionally, to networks of mutual acquaintance or recognition relationships". Again, in elaboration of Milani (2002-205) derived from Robinson (2002), social capital refers to "a group of resources accessible to individuals or groups while belonging to a network of mutual acquaintance. This network is a social structure and has aspects relationships, norms and trust that help develop the coordination and cooperation that produce common benefits." The relationship among the agents in an instution is highly valued and measured. The interaction of the agents leads to collective actions which benefit members of the institutions.

There are two important kinds of social capital need to be acknowledged; bonding and bridging social capital. The basis of bounding social capital is a common identiy which include family, ethnicity, religion, and culture. These bases are recoqnized to be able to create trust, cooperation, collective action, and learning (Knorringa and Van Staveren: 2005). Meanwhile, bridging social capital happens in a heterogenous community that have different background of identity, and come from different group. It is argued that bounding social capital can impede the wider interaction outside the group if it is not completed with bridging social capital.

The paper will analyse the existance of social capital in clusters of tourism in Borobudur. The paper raised an issue that to which society that social capital actually benefit for because only a few members have the access to benefit from resources. While when it is proven that only certain members having the access to certain resources useful for their businesses, the strong ties of social capital might bring negative impact for those who only have a few or no network with anyone engaged in the business environment. This could bring inequalities instead of advantages for all members.

\section{Result of the Study}

To develop small and medium enterprises, government of Magelang regency and the tourism enterprises at Borobudur district establish tourism cluster which is found to agglomerate in the area. Since 2005 to 2012, local government has facilitated five clusters. One of them is tourism cluster. Cluster Dialogue Forum (FRK) became one 
of the best clusters in Central Java province since this group is considered to be active in conducting coordination among stakeholders either formal or informal ways such as Local Work Unit (SKPD), Forum for Economic and Development (FPESD), and Forum for Economic Development and Employment Promotion (FEDEP), Germany Internaional Cooperation (GIZ), and other important supporting institutions.

\subsection{Descriptive statistic analysis}

The existence of FRKPB has been considered to play seminal role for local development in Magelang regency. This condition is driven by active participation of the cluster members to initiate programs and activities. They have been involved in several activities such as joint marketing, andong-hourse car joint provision, mask art performance organizing, etc. The initiatives and the interest of the members of FRKPB are actively discussed in their dialogue platform. The dialogue is found to be routinely executed. There are as many as $88 \%$ of the members that have been actively involved in the meeting. And, there are $90 \%$ of the members consider that these routine meetings are important to join. It is found that the public figure in the society plays considerable role to run the meeting well.

\subsection{The role of formal institution towards local economic development}

One of initiatives that can be done is to develop existing resources and potentials to benefit the community and local government. This will improve the income of the society. Table 1 indicates the income improvement of the members of FRKPB.

TABLE 1: Descriptive Statistic of the Income of FRKPB members.

\begin{tabular}{l|c}
\hline Statistic Value & Income (Rupiah)/Month \\
\hline Mean & 1.208 .000 \\
Maximum & 2.000 .000 \\
Minimum & 300.000 \\
Modus & 1.500 .000 \\
Source: Primary data, processed
\end{tabular}

Table 1 indicates the average income of the members of FRKPB. There are 50 respondents and have average income Rp. 1.208.000/month. The highest income reaches Rp.2.000.000. This highest income (94\% of members) is influenced by the time they have joined the FRKPB. The lowest income ( $6 \%$ of members) reaches RP.300.000. This 
is also influenced by the time joining the forum. These members are found to join or involve in a few activities. The data shows that among these fifty respondents, the highest income members are affected by the involvement in the dialogue, meeting, and other cooperation or activities. This happens due to the active members often receive and are easier to get access of information related market, program, and joint cooperation as in Figure 2.

\section{The Increased of Income}

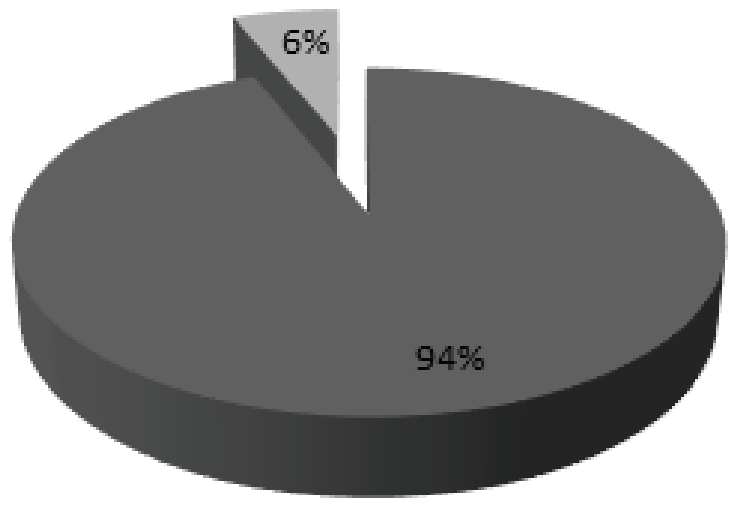

Yes

No

Figure 2: The increase of income of the FRKPB members.

The income of the members is considered to be affected by the product promotion. The products include the crafts and the other kind of cultural activities performed by the society in Borobudur in the peak season such as on holidays. The condition of promotion is illustrated in Figure 3.

Figure 3 illustrates that there are $92 \%$ of the members promote their products actively. The rest, $8 \%$ of the respondents/the members do not promote their products actively. Commonly, the promotion is also suppported and accomodated by the local and provincial government. Several supporting activities are training on information technology for promotion and marketing such as through websites, social media, unique brochures and leaflets, etc. Besides, they are also actively involved in cluster exhibition either at local, regional or national level. However, the challenge seems to be the sustainability of the programs which are possible to make the members of the clusters less depend on the facilities from the government or other institution. To achieve this, continuous trainings to improve the capacity or skill of the members might be required. 


\section{Promotion Activities}

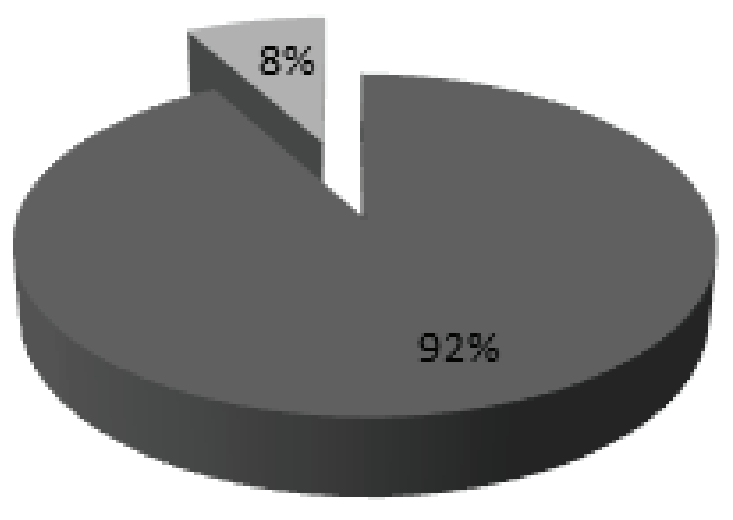

Active

Not Active

Figure 3: Promotion activities.

\subsection{Typology analysis of Borobudur tourism cluster (FRKPB)}

The establishment of cluster stimulates the local economic empowerment in Magelang. Several benefits of the cluster found are:

1. The establishment of the cooperation among the members of the FRKPB with other external supporting institutions.

2. The exchage of information and knowledge

3. The cooperation on marketing with related stakeholders.

4. The existence of innovative products

Based on the condition in Borobudur Tourism Cluster, FRKPB can be classified into a dynamic and active cluster. These can be suited with several aspects such as products, technology, information access, supporting institution, and institution exists in the cluster. Borrowing the cluster classification from JICA in Bank Indonesia (2006), the active and dynamic cluster involve the one that can develop the products, technological exchange, and market information, and also joint activities. Dynamic cluster is when the cluster itself has been specialized, create new products, and has strong institutions in developing cluster programs.

In this research, it is found that FRKPB is included as an active cluster in relation to the joint activities they often do. One of them is conducting routine dialogue. As 
mentioned earlier, there are $88 \%$ of the members are activly joining initiatives such as promotion, discussion either at local, regional, provincial, and national level. From the perspective of product development, FRKPB has classified its own specialisation which is quite significant. This has made the program development assistance, cluster product promotion, and business unit development itself are easier to execute since they have various needs. New products which are initiated by the members of FRKPB are found in the form of many new various tourism destination packages. These are essential to make the Borobudur site having more attraction for tourists. For instance, local indigenous cultural performance, and the visit to the center of local business unit such as handycraft, ceramics, fiber glass, etc.

However, it is found that only certain people could join the exhibition or promotion facilitation from either local, provincial, or national government. When interviewed, there is one very active member of the cluster who has been trusted by the other members of the group to represent the members joining any exhibition programme conducted in the local or regional area, and even in the national level. Some products of the cluster's members are brought in the exhibition. When asked further, there is not definite agreement among them. For example when the products sold, how they will manage the profit, the operational cost for exhibition, transportation, etc. This condition can be interpreted that there is a very strong tie of social capital in the term of joint promotion to lessen the operational cost. This kind of bonding social capital is quite strong making it easier to the cluster in managing the members to have joint product promotion in which can make them spend lower cost for operational.

However, seeing the fact that only one or two active members involved in joint product promotion event making the condition unequal. This unequality happens in term of opportunity for the other members joining the similar events are less. As we can see that fact that when having the exhibition, it is a good chance for all business players or enterprises to have wider network with other people visiting their booth or promotional place. It is also a good chance for SMEs to introduce their products or new innovation, and their own brand to society from different places. Even if they promote the products on behalf of the name of Forum Rembuk Klaster Pariwisata Borobubur (FRKB), it is supposed to be consisting of different brands or product names.

Having said this, in the long run, the FRKPB is difficult to develop every members' capacity in term of establishing more networs as all opportunities are given to only certain members in which, actually, making the condition of the members unequeal. This unequality is in term of having the same opportunities to see wider network or 
to create better bridging social capital. Therefore, in this case study, there is unseen inequality among the members of the cluster.

\section{Conclusion and Recommendation}

This research concludes some points:

1. Social capital plays significant role in the dialogue cluster forum success. It is the trust of the members to the public figure of the society and to the government. This can be seen from the existing programs accomodated by the government such as assistance program, and partnership establishment with either internal or external parties.

2. There is a strong tie of social capital in the cluster of FRKPB. The bonding social capital has proven to make the members easier to manage activities conducted together. One example which is dicussed in having joint product promotion.

3. The bonding social capital has also proven to benefit the clusters. However, it creates inequality for other members of the clusters who have less or even no access to outside network. The inequality happens in term of the opportunity for every one to have similar access to information, facilities, and others. The trust they have already successfully built brings access only for certain people.

4. From economic perspective, Cluster Dialogue Forum (FRK) is proven to enable the improvement of income generation to the members. This is driven by the easier access to information related to programs offered or initiatives by other members of the FRKPB or any related stakeholders. For instance, the information on access to market and wider potential buyers, and new products development that have more economical values. Therefore, the local potential can be developed and empowered.

5. Tourism cluster of Borobudur can be classified into active and dynamic cluster. This is seen by the existence of product and service innovation offered to visitors. The members of the forum are categorized into active members. This is not only due to their presence on the dialogue forum, but also their initiatives to develop better programs with the government and other supporting institutions.

Based on the above, it is expected that: 
1. Government as the regulator and related stakeholders for tourism can actively be involved in the cluster dialogue forum. Tourism plays significant role for the development of economy in Magelang regency.

2. Cluster dialogue forum is an element in the cluster functions as a locomotive for the success of the programs of cluster since it consists of business enterprises that acknowledge the existing condition. They need support from many interest parties. It is expected that the programs could be better continuously executed.

3. One of important programs in cluster is cluster product promotion and its institution. Hence, there is a need for training program related to the use of technology for promoting cluster dialogue forum products, services, and ideas. This is required to widen the market of the cluster members to be more globally known. Hence, the members are expected to have more information access on market to increase their income or to inform their interest to further develop their potentials for local economic development.

4. Therefore, as to ensure all existing opportunities can benefit all members, government, especially at the local level, shall create better conducive business climate by better knowing all members of the clusters and open wider access for everyone to get direct benefit from the access given by the government or any related development actors. To make this happen, there is a need to them to improve the capacity of all members of FRKPB.

\section{References}

[1] Andersoon, Thomas,dkk. 2004. The Cluster Policies Whitebook. IKED. Sweden

[2] Asheim 1994; Schmitz and Musyck 1994; Rabelloti 1995 in Peter Konorringa 1999

[3] BAPPEDA Kabupaten Magelang. 2011. Laporan Rencana Bisnis 2011. Kab. Magelang

[4] Bhatarcarya, GK \& RA Johson.1977. Statistical Concept and Method. New York: John Wiley \& Sons, Inc.

[5] Danim, Sudarwan. 2002. Menjadi Peneliti Kualitatif. Bandung: CV. Pustaka Setia

[6] FPESD.2005. Profil FPESD. Semarang. FPESD

[7] FPESD JATENG. 2010. Rapat Kerja

[8] Jaya, Wihana Kirana, 2006, Artikel: Peran Institusi dalam Pertumbuhan Ekonomi, Universitas Gadjah Mada.

[9] JICA. 2004. The Study on Strengthening of SME Cluster in Indonesia, 2004. Final 
[10] Report. JICA and Republic of Indonesia Ministry of Industry for Economic Affairs

[11] Knorringa, Peter. 1999. Cluster Trajectories and The Likehord of Endogeneus Upgrading. Netherlands. Institute of Sosial Studies

[12] KRI International Corp. 2004. Studi Penguaton Kapasitas Klaster UKM di Republik Indonesio. JICA

[13] Kuncoro, Mudrajad, 2004, Metode Kuantitatif Teori dan Aplikasi Untuk Bisnis dan Ekonomi, UPP AMP YKPN, Yogyakarta

[14] Miles, M.B \& Huberman, A.M. 1984. Qualitative Data Analysis, A Sourcebook of New Methods. SAGE Publications, Baverly Hills, London, New Delhi

[15] Muhadjir,Noeng.1990. Metode Penelition Kualitatif. Penerbit: Rake Sarasin, Yogyakarta. Hal 13-34

[16] North, Douglass, 1990, Institutions, Institutional Change and Economic Performance, Cambridge University Press.

[17] Porter, Michael.1998. The Competitive Advantages of Nation. New York. The free press

[18] Richardson, Harry W. 2001. Dasar-Dasar Ilmu Ekonomi Regional. Edisi Revisi. Terjemahan Paul Sitohary. Jakarta. Universitas Indonesia

[19] R. Supriyadi, Ery. 2007. Telaah Kendala Penerapan dan Pengembangan Ekonomi Lokal: Pragmatisme dalam Praktek Pendekaton PEL. Jurnal Perencanaan Wilayah dan Kota, Vol 18 No. 2 Agustus 2007 Hal 103-123

[20] Schmits H. 1995. Collective Efficiency: Gwoth Patj for Small Scale Industry. The Journal of Development Studies. Vol 31. No. 4. April 2005529.566

[21] Strauss, Anselm and Corbin, Juliet.1990. Basics of Qualitative Research: Grounded Theory Procedures and Techniques. Sage Publication.

[22] Sumodininggrat, Gunawan. 1998. Membangun Perekonomion Rakyat. Cetakan Pertama, Pustaka Pelajar, Yogyakarta.

[23] Tarigan, Antonius. 2005. Bunga Rampai Pembangunan Kota Indonesia dalam Abad 21: Pengembangan Ekonomi Lokal di Kabupaten Tanggamus. Jakarta: Yayasan Sugijanto Soegijoko-URDI

[24] Timur, Sledjan; Getz, Donald. 2008. A Network Perspective on Managing Stakeholders for Sustainable Urban Tourism. International Journal Of Contemporary Hospitality Management, Vol.2.No.4, 2008. Hal 445-461. Emerald Group Publishing Limited. 